\title{
EFFECTS OF DECIPHIRING IN PIANO EDUCATION BASED ON WORK ANALYSIS ${ }^{1}$
}

\section{Lecturer Dr. Çağlar BAKIOĞLU*}

\author{
Assoc. Prof. Dr. Yakup Alper VARIŞ*** \\ Correspondent Author: *Trabzon University Faculty of Education, Department of Music Education, caglarbakioglu@trabzon.edu.tr \\ * Ondokuzmayls University, Faculty of Education, Department of Music Education, yalperv@omu.edu.tr
}

\begin{tabular}{|c|c|}
\hline Article history: & A b s t r a c t \\
\hline $\begin{array}{l}\text { Accepted O1 September } 2019 \\
\text { Available online } 31 \text { December } 2019\end{array}$ & $\begin{array}{l}\text { In this study "Piano Lesson Analysis Form" was developed and intended to provide a thorough } \\
\text { analysis in the work of a piano piece, at the time of the study or before playing it. This developed }\end{array}$ \\
\hline Keywords: & form allowed us to determine what is effecting the skills of the students in sight reading. In this study, \\
\hline Piano Education & nd post-test control group desion, the assessments were made with between- \\
\hline Work Analysis Form & \\
\hline Deciphering & groups and within-groups comparisons. In the study, results in the first period of both groups were \\
\hline Deciphering in Piano Education & obtained and sight reading study was made. After these implementations, the other piano pieces that \\
\hline Work Analysis in Piano Education & $\begin{array}{l}\text { were deciphered by the experimental group and the homework assignments of the piano lessons } \\
\text { studied throughout the semester and examined with "Piano Piece Analysis Form for the Piano }\end{array}$ \\
\hline & $\begin{array}{l}\text { Lessons". Based on the results of pre-test and post-test comparisons, it is observed that there was a } \\
\text { significant difference in terms of the sight reading skills. }\end{array}$ \\
\hline
\end{tabular}

\section{Introduction}

The importance of the piano in the instrument training which aims to make the candidates of music teachers competent, knowledgeable and equipped in their instrument that requires discipline and patience (Akyürek, 2018), is a recognized fact all over the World.

In Turkey, the music departments of the universities as well as the other music institutions, are in consensus that music teachers should learn adequate keyboard skills that are acquired during the process of music education. Keyboard competence is considered as a skill that should be acquired for all students studying music (Baker, 2008). Teachers, researchers and academicians working in many institutions and organizations think that piano education is not only a training for pianists but also a training process that every musician should take.

Piano education can be defined as all of the processes applied to gain new behaviours that have aesthetic, musical and technical characteristics for individuals (Y1lmaz, 2006). According to
Kurtuldu (2007), the method of repetition and organizing plays an important role in the cognitive perception of the student in piano education. In this process, in which the student is active, reinforcement is done by repeating. The process of repetition should be divided into certain parts, not from beginning to end. This process of repetition can be done by dividing the work such into sentences, motifs and periods. This method facilitates the learning process of the work while increasing the retention. For this reason, the works studied in piano education should be divided into pieces and repeated in certain time periods.

\section{Deciphering Skills in Piano Education}

If we compare the universal music to a language, the notes can also be regarded as the alphabet of that language. Being able to pronounce notes in a work correctly can be compared to the correct reading of the texts in that language. Performing regular exercises in order to be able to read quickly and accurately ensures the development of talent by eliminating the deficiencies

\footnotetext{
${ }^{1}$ The study is a part of the first author's doctoral dissertation (supervised by Assoc. Prof. Dr. Yakup Alper VARIŞ) entitled "Effects of Deciphering in Piano Education Based on Work Analysis"
} 
in that subject. Students who have difficulty reading notes can minimize this problem by doing regular exercise. The better a person can read, the more he / she can reach different types of books and improve his / her reading. So like reading, the music students can reach different types of music more easily, thus improve their music taste, repertoire and interpretation that can provide them easier transitions to other steps in the educational process (Özer, 2010). It can be thought that deciphering can make a significant analysis of the given notes and contribute to other areas of music education.

Deciphering, which comes up with similar names in the literature such as playing deciphering, reading deciphering, is an important and indispensable element that exists in all areas of music education. Deciphering, which is a guide and assistant for all activities of a musician's professional life, is among the most important skills expected from a musician (Kurtuldu, 2014).

When the relevant literature is examined, it is possible to come across studies that reveal the place and importance of deciphering studies in piano education (Küçük, 1994; Kurtuldu, 2014; Özer, 2010; Selen \& Aşkın, 2009; Tufan, 2000).

Öztutgan and Akbulut (2019) state that deciphering is one of the main qualities that should be present in each individual engaged in music, and that the factors that may affect the dimensions of deciphering are composed of learning, reading and vocalizing. As in every scientific field, making an analysis in the field of music has an important place. In this context, the student's ability to what he/she sees can be seen as an equivalent to deciphering.

The ability of a student to read (decipher) what he/she sees directly affects the speed and quality of musical learning, especially in beginner and advanced levels. In addition, this ability, which helps students become independent musicians, can also be regarded as an indicator of a musician's level of musicianship. For this reason, many universities, orchestras, or any music institution or ensemble measure the ability to decipher to have better musicians. Students who develop better deciphering skills can learn new music faster and improve their self-confidence by increasing the level of correct playing on the instrument (Kuo, 2012).

Çimen (2001) defines deciphering, which is accepted as one of the most basic skills of piano education, as playing or reading notes of a music at first sight without any previous work. The high level of deciphering skills helps the student to learn faster and more accurately, but also makes the learning more enjoyable and enables the student to love his instrument and move forward more quickly. Students who do not hesitate to study new notes increase their interest in learning. Thus, the students who are good in deciphering improve their talent with the opportunity to get to know the richness of the piano literature such as style, technique and interpretation. A student with these characteristics can develop himself / herself and become an independent musician without the help of others and create a source foe music that he/she can enjoy throughout his life (cited by Küpana, 2012). Individuals who can provide self-learning with the ability to analyse can improve themselves by enjoying music. At this stage, if we take deciphering as the ability to analyse, we see that it is used in two dimensions in music.

According to Fenmen (1974), there are two types of deciphering. Generally speaking, the first one is to examine the piece slowly when we first have it and read every note, while the second type of deciphering is to read the piece at first glance at a speed close to its tempo. The first deciphering type is made for the works that we intend to play in full. The aim of such studies is to bring the work to our repertoire. For this reason, it should be read by paying attention to all the features of the work on paper. The purpose of the second deciphering type is to improve reading faster. In this deciphered form, while performing instant work, it is necessary to play as close to the tempo of the work as possible.

It is more likely to play a selected work below students' level at a speed close to its original tempo. In this way, the students can improve the ability to play at the moment when they see the work just by focusing on the notes. In this process, trying to play the work with the right and clean notes as much as possible makes us think that the student's learning skills will improve.

Since the aim is to have a new piece in repertoire, it should be done carefully and accurately. It can be thought that all the features of the work will be analysed and learned thoroughly and will contribute to the development of technical skills as well as its accuracy.

According to Tufan (2000), considering the benefits of deciphering skills and the extent to which these benefits will reach, the following can be reached.

a) Enjoying the work

b) With the improvement in note reading speed, the instrumental skill also shows a rapid improvement

c) Wondering new works to play with the desire of making and getting them

d) Piano repertoire development

e) Development in musicality

f) Recognizing accompanied instruments and knowing the music types

g) With the development of music culture enjoying more music. 
The individual can obtain these gains by analysing the music works well. It can be thought that the gains obtained will contribute to the musical development of the person as well as understanding the music correctly. It's either the technical development of the piano, the right method of operation or good deciphering skills mainly brings success and the factors related to success into mind.

\section{Analysis in Piano Education}

If an effective piano education has been chosen as the goal, the student's questions about music must arise in order to achieve this goal. In order to better perceive music and express it back, students should be in search of what kind of things can be done. In short, "Musical Analysis in Piano Education" is an imperative to approach piano education analytically with this understanding (Bağçeci, 2003). It can be said that the examination of the piano works, which have many fields of knowledge in technical, musical or cognitive ways, makes it possible to separate them under these headings as much as possible, to analyse them in general terms and to make the difficult parts into perceptible information.

Accurate perception of the difficulties in the technical and artistic content of a musical work is seen as the main basis of mastery (Demirova, 2008). Musical analysis is one of the first steps in learning, considering that it is a sub-step of mental perception of knowledge.

When creating music, it is essential to think analytically in many areas. Especially because of the use of cognitive, affective, sensory and dynamic fields used by the person during performance, these fields need to interact based on each other. Providing this interaction will provide a higher level of vocalization. For this reason, analysis should be made in terms of both technical and musical disciplines (Bağçeci, 2003). Considering the function of nuances and articulation signs in the transmission of musical emotion, it can be said that analysis of such areas is also important.

Before the deciphering of a work, having a prior knowledge of the work enables the deciphering process to take place in a shorter period of time. In this context, deciphering is a skill that has many sub-dimensions, which can develop as you work and that musicians need to use throughout life (Çiftçibaşı and Şaktanlı, 2017). Given the importance of deciphering throughout a musician's life, it can be seen that it should be developed as much as possible. In this context, it can be said that a good analysis is needed for better decoding. The ability to decipher can also be considered as the power to analyse the note they see. It can be said that the power of this analysis is highly utilized while learning a work.
When learning a new piece on the piano, starting by analysing the piece first makes it easier and more robust to learn. A pianist who can be analytical can see himself as a musician. Evaluating and discussing musical objects from different angles can create the most enjoyable and effective way to achieve the goal that determines the strategy (Selen and Aşkın, 2009). According to Chaffin and Imreh (2002), when preparing a notation for performance, a performer will go through several stages, such as dismantling, working on, and reassembling (cited, MacRitchie, 2017).When the student is learning a new piece on the piano, he or she may need to develop an insight into how to plan to play the piece he / she wants to learn.

During the piano education process, the students will be able to analyse and understand the works they have played with the theoretical information they have learned, and it will enable the students to interpret that work and add their own interpretation. In this aspect, it is seen that musical analysis plays an important role in the interpretation of the work in a systematic way (Bulut, 2008). In order for a pianist to be a full musician, he/she has to take an analytical approach. The fact that the musician is able to understand the content by analysing the music of the works can be interpreted as he/she have the background information.

It can be said that the first step is to reveal information considering that it is necessary to reach information in order to learn and make it functional. Looking at the whole while studying a piano work, it can be seen as a ball of knowledge. Accordingly, the learning process can be perceived as difficult in the eyes of the students. If we think that it is not impossible to play any piano piece, it would not be wrong to think that there is a way to play the existing piece. For this purpose, the student may need to try to see what is invisible to the eye in the learning process. The use of behaviours such as thinking, trying to understand, trying to play will help.

It may be necessary to form some analytical questions in order to make learning easy, fast and accurate considering that there are many technical and cognitive knowledge in piano works. Through these questions, the student improves himself / herself and at the same time decomposes all the knowledge of the work. Once the disaggregated information is learned both technically and cognitively, the merging process can start. Thus, the information consisting of small pieces is combined in order to reach the information contained in the whole piece.

When learning a new piece, one of the useful approaches is by summarizing the structural and style features such as musical elements, form and period of writing. Recognizing the piece in terms of music elements and their complementary patterns will help the student to understand the musical ideas in that piece and make simple analyses from it (Ercan, 2008). 
Piano students, focusing only on the notes without paying due attention to all the features of the work they play, may decrease the quality of the work. In addition to deciphering, this may negatively affect the academic achievement and attitude towards the piano lessons. The work analysis form, which was developed in order to eliminate these negativities, can help the student to become more familiar with the work while paying attention to these characteristics. Thus, since he/she can see the work in every sense, not only with its notes, a more accurate and faster learning is expected. For this purpose, it was planned to compare the data obtained by using the deciphering scale for the piano lesson and "Piano Lesson Analysis Form" to contribute to the piano education processes. In this context, the research question of this study was "What are the effects of the music teacher candidates' analysis on the works they have learned in piano education processes with their basic features and pre-studies through work analysis to their deciphering skills?".

\section{Purpose of the Study}

The aim of this study is to determine whether the music teacher candidates' analysis on the works they have learned in piano education processes with their basic features and have an effect on the deciphering skills or not. On the other hand, it is aimed to determine the effect of "Piano Lesson Work Analysis Form" which is developed and to test its usability.

\section{Importance of Research}

The research is important in terms of aiming to contribute to Turkish music education by determining whether the analyses on the works during piano lessons made by music teacher candidates effect sight reading skills of the piano or not.

\section{Research Model}

In this study which has a pre-test/post-test control group design, screening model was also used and expert opinion was also applied.

Kerlinger (1973) pre-test/post-test control group design can be defined as a system which assigns subjects into experimental and control groups neutrally and evaluate them before and after manipulation (X) (Büyüköztürk, 2001:22). In this context, after determining the equivalence of the subjects, they were assigned to experimental and control groups objectively.

$\begin{array}{ccccc}\text { EG } & \text { R } & \text { O }_{1} & \text { X } & \text { O }_{3} \\ \text { EC } & \text { R } & \text { O }_{2} & \text { X } & \mathbf{O}_{4}\end{array}$

Figure 1. Pre-Test/Post-test Control Group Design

In figure 1, EG represents experimental group, CG represents control group, R represents neutrally assigned subjects, $\mathrm{O} 1$ and $\mathrm{O} 3$ represents the pre-test and post-test measurements of the experimental group, $\mathrm{O} 2$ and $\mathrm{O} 4$ represents pre-test post-test measurements of the control group and $\mathrm{X}$ represents the independent variable that was applied to the subjects in the experimental group. The practice to be performed according to the pre-test/post-test methods are given in Table 1.

Table 1. Practices to be Performed According to the Pre-test/Post-test Methods

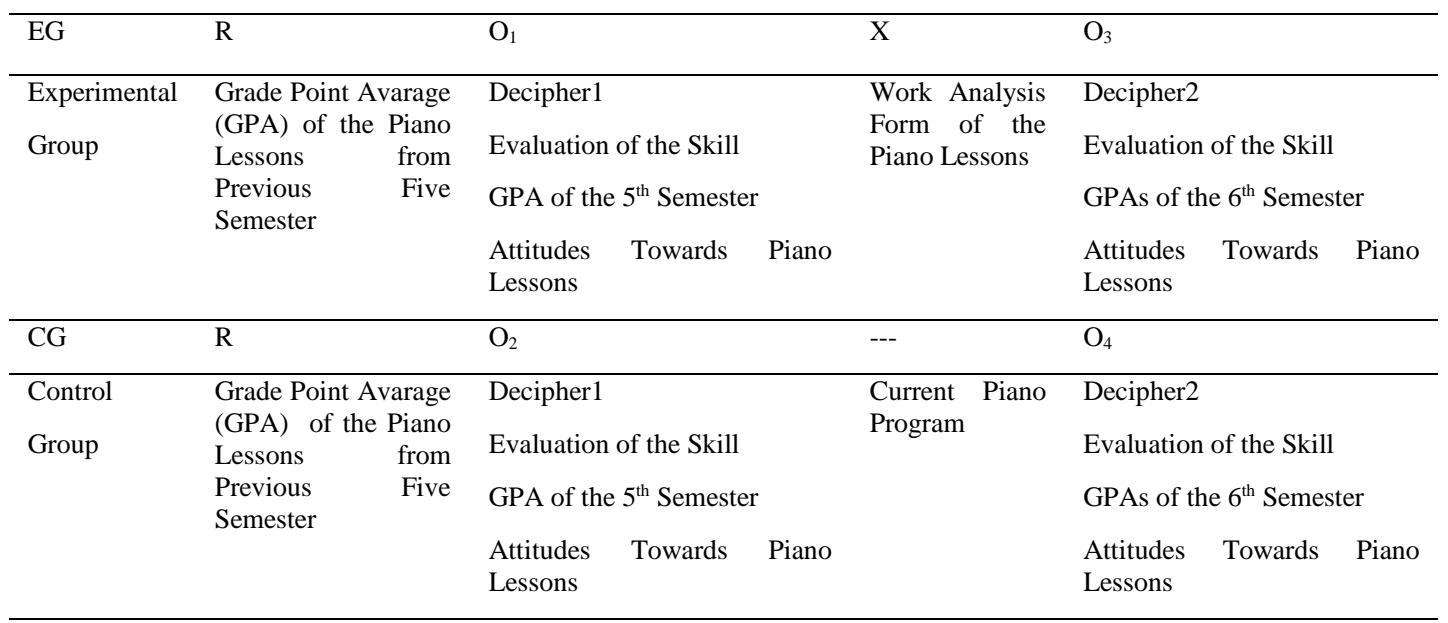




\section{Determination of Experimental and Control Groups}

For this study's experimental and control group 16 (8 for experimental group and 8 for control group) Junior Year students were selected from Trabzon University, Fatih Faculty of Education, Department of Fine Arts, Music Teaching Program. In order to make a comprehensive analysis of the piano work, it was preferred to work with the class that reached the most intermediate level in the piano class as much as possible. There is no piano lesson in the Senior Year due to the renewal of the curriculum in the department. Therefore, in the 2nd semester of the Junior Year the students have the most advanced piano education

This research, ground on the neutrality of the subject assignments of the groups. For this purpose, the piano Grade Point Average (GPA from now on) of the first five semesters was accepted as the basis. In order to represent all success levels of the subjects in both groups, they were matched with each other and then distributed to the groups by neutral assignment. This way was chosen to prevent the group of students with high GPA end up in one group and students with low GPA in the other. In order to ensure the equivalence of the selected students, the GPAs of the first five semesters were examined and equivalent students were identified. Piano course's academic achievement is determined and equivalent students whose scores are closest to each other were considered. It was taken care that the difference between the achievement scores of the matched students did not exceed more than 5 points. After the difference between the average scores of the groups in pairs not exceeding 5 points, it was decided objectively whether which student will be in the experimental group and which will be in the control group and then assignments were made.

In order to get the GPA of the selected students, they should not fail the piano course of previous semesters. In the first stage, 26 students were identified that matched these conditions and matched each other. These 26 students were matched with each other and 13 experimental and control groups were formed. However, the number of groups had to be reduced from 13 to 8 due to some negativities in the research's process. 5 groups (10 students in total consisted of 2 students for each) were excluded from the study due to the unexpected negativities such that some students worked without completing the "Piano Lesson Analysis Form" and some students were not thrilled during the deciphering video recordings. Experimental and control groups of 8student were determined. The piano GPA of these students are given in the table below.

\section{Data Collection Process}

While the pre-test and post-test deciphered works, which are used in the experiment process, are developed by experts, to evaluate the video recordings that were used in the piano deciphered works, "Decipher Evaluation Scale" developed by Kurtuldu (2014) was used in order to evaluate this information. Researchers prepared some tools and equipment using experts' ideas. While scoring and suggestions were taken into consideration in determining the deciphered works, Lawshe technique was used in the development of "Piano Lesson Work Analysis Form".

\subsection{Piano Lesson Work Analysis Form Development Process}

When creating a piano work analysis form, a pool of items was created in order to help subjects to analyse the piano work thoroughly. In this item pool, it is aimed to know the character traits of the work as much as possible. In this sense, 32 items which can help the student to realize the characteristics of the work such as number of measurements, tone / tonality, melodic structure, rhythmic patterns, changer marks, nuances, articulation marks are included. In addition to these cognitive items, eight affective and psychomotor items were prepared to determine the first impressions of the subjects about the work. While developing the "Piano Lesson Analysis Form", expert opinion was used to determine the comprehensibility and suitability of the items for the target audience. In the first stage, the item pool that was prepared in the cognitive-affective-psychomotor fields was first tried to obtain the most appropriate expressions in Turkish by consulting a specialist in the Department of Turkish and Social Sciences Education. Subsequently, the items obtained were reviewed in terms of education in consultation with an expert in Educational Sciences and made ready to be sent to the experts. This pool of materials was then sent to 10 music educators specializing in piano. According to the feedback from the experts, it was proposed to remove the affective and dynamic field items and it was considered that it was more appropriate to analyse only in the cognitive field. Therefore, only the cognitive domain items were improved.

The necessary explanations for the parts that are not deemed appropriate or required to be corrected by the experts have been taken and the "Piano Lesson Work Analysis Form" has been finalized and made ready for use with 28 items with the help of Lawshe technique. 


\subsection{The Process of Identifying Deciphered Works}

The deciphered works used as pre-test/post-test were written by the researcher. This method was used in order to eliminate the possibility that the transcription works had been seen, heard or sung by the students before. In this context, the researcher has created five works with different characteristics and asked the experts to determine whether they are appropriate for the pre-test and post-test, if appropriate, to select the most appropriate ones, if not, how to make corrections. In order to make these evaluations, five works were sent to experts with voice scales and note scales, as well as evaluation scales, where they could indicate their comments. Experts stated their opinions about the work by scoring and commenting. In line with the feedback received, the highest score was accepted as the pre-test and the second highest score was accepted as the post-test. Based on these results, pre-test and post-test works that will be used to measure the deciphering skills of the subjects were determined.

In order to determine the pre-test and post-test deciphering skills, 5 works with different characteristics were first sent to 12 music education piano specialists. For these works, a scale prepared by the researcher for the experts can make scoring and commenting.

In order to prevent the works used as pre-test and post-test to be based on one feature, each deciphering works have different features than the others. The works submitted to expert opinion have the following features; Decipher 1; There are two harmonious and monophonic successive melodies that are very similar but not exactly the same for the right hand and the left hand. Decipher 2; simple figures and chords are written for the left hand whereas main melody for the right hand. Deciphering 3; the left hand gives an octave bass sound while the right hand has a main tune greater than 1 octave. In the second part, if we consider the number of measurements as $4 / 4$ as $8 / 8$, it is given as $4+4$ in the left hand and $3+3+2$ in the right hand. Decipher 4 ; 2 or 3 voice tunes were used instead of monophonic sound, including the main melodies in the right hand and left hand. Decipher 5; a melody in the right hand and left hand is exactly the same.

Every experts opinion and scoring were needed for this work. It is stated that the first two works with the highest scores will be pre-test and post-test. In addition, suggestions and comments about the works received by the experts via phone calls and emails were also evaluated.

Incoming feedbacks were converted to numerical values by making content analysis, so that two works could be determined to be used as a pre-test and post-test among five works. According to the feedback received from the experts, among 5 works the highest score was obtained by decipher 1 and the second highest score by decipher 2. As mentioned while taking expert opinions, it was determined that the highest score obtained by deciphering 1 used as pre-test and the second highest score by decipher 2 as the post-test.

\subsection{Experiment Process}

The "Piano Lesson Work Analysis Form", whose development was completed, was applied to the experimental group. This form was filled in before any studying or the practising was held by the subjects. The experimental group, consisting of Junior Year Spring Semester students, completed the form for each piano work they should play during the education process. In addition, they have completed the form for works that were selected as deciphering 1 and deciphering 2 to determine their deciphering skills. The experimental group used the "Piano Lesson Analysis Form" for both the piano works played in the midterm and final exams and for the determination of their reading skills.

\subsection{Determination of Experimental-Control Groups and Ensuring Equivalence}

Students from Trabzon University, Fatih Faculty of Education, Department of Fine Arts, Music Teaching Program Junior Year and Spring Semester were selected for the experiment, during piano lessons in an academic year (14 weeks) once a week for one hour.

In accordance with the study, the equivalence and neutral assignment of the subjects should be ensured. In order to make equivalence and unbiased assignments, the piano GPAs of the subjects were taken as basis. After obtaining the necessary legal permissions, a 5 semester GPA was reached. The arithmetic mean of five semesters was calculated for each student in the class list and they were balanced with each other to form the experimentcontrol group. The first five semesters of the piano course averages were compared and the subjects were matched with each other and randomly assigned to the experimental and control groups. The experimental group students completed the "Piano Lesson Analysis Form" for each piano work from the first week and the control group continued their courses in accordance with the curriculum without doing so. All subjects were pre-tested for deciphering skills and recorded on video.

Post-test applications were performed for the deciphering skills of the subjects and the videos were recorded. In this application, the experimental group completed the "Piano Lesson Work Analysis Form", and the control group was given time to recognize the work without using the form. After the end of the midterm exam, the experimental group completed the "Piano 
Lesson Analysis Form" for each of these works. The control group did not complete this form and continued their courses according to the curriculum.

\subsection{Deciphering Skills}

In the practice, the process of deciphering the works of art was recorded on video. This method was preferred in order to make it possible to reach the expert juries who will make the evaluations. Because of the objective and validity of the evaluation process of the skills in the deciphered pieces, connection established with as many juries as possible and 12 academicians in the piano branch. Subjects and juries were divided into four groups and matched with each other. 3 participant were involved in each jury groups and 5 or 6 participants were involved in test groups. Thus, each jury evaluated 5 or 6 people and each subject were evaluated by 3 juries. The reliability of the numerical data was tried to be increased by the evaluation of the subjects by 3 juries.

In order to measure pre-test and post-test deciphering skills, the selected works were played by the subjects and this process was recorded on camera. Before the works were played, the experimental group was filled in the "Piano Lesson Work Analysis Form", and the control group was given time to recognize the work. Then, these records were sent back to the experts with the "Deciphering Assessment Scale" and the subjects were asked to score their deciphering skills. The arithmetic mean of the scores obtained from the 3 experts that evaluated at least 5 or 6 student. The scores obtained for the pretest/post-test were compared with each other and the data were compared with the experimental and control group.

Experimental and control groups were asked to play the deciphered work. Firstly, after giving time to study the work, the first performances were recorded. Both groups were deciphered without using any method. The data obtained from there form the pre-test part of deciphering skills. The data obtained from the post-test applications were first compared with the pre-test data in the group, then the results were compared with the experimental and control groups.

In the post-test application for deciphering skills, a second deciphering piece (deciphering 2) was played to the subjects and the video was recorded. The experimental group completed the "Piano Lesson Analysis Form" before they started, and the control group did not complete the "Piano Lesson Analysis Form". The control group was asked to analyse the work in accordance with their wishes and to allow them to recognize the work. Then, the played works were recorded by video and sent to expert teachers with "Deciphering Assessment Scale" and they scored. The data from the experts were compared with the pre- test results of the groups themselves and the general data of the experimental and control groups.

\section{Data Analysis}

Since both qualitative and quantitative data collection techniques are used in this research, quantitative and qualitative analysis methods are used in the data analysis stage. The qualitative field was involved in developing the data collection tools of the study and the creation of the "Piano Lesson Analysis Form" while the quantitative field was included in the pre-test and post-test section.

A known statistical package program was used in the analysis of the quantitative data of the study. In statistical transactions, average score calculations for data, reliability coefficient and comparative measurements were performed respectively. In the scoring process of the deciphering works, "Deciphering Assessment Scale" was used and scored by four jury groups consisting of three people. The scoring process and data are explained in detail in the tools used and developed above. After obtaining the course lists (6 semesters) related to the academic achievements of the study group, the arithmetic average of the related course notes was obtained. While the average of the first five semesters of these lecture notes determines the equivalence of the groups, the fifth and sixth term averages constitute the pretest and post-test parts of the academic achievement of the subjects. After completing the process of obtaining descriptive information for the concept of deciphering, the process of comparing the data obtained from the experimental and control groups was initiated.

Comparative measures (Mann Whitney U test - Wilcoxon Signed-Rank test) were used to evaluate the scores obtained from the deciphering process of the experimental and control groups. In the measurement of the obtained scores, it was considered that the students in the experimental and control groups could not meet the assumption of normality because of the small number and therefore non-parametric tests were preferred. In comparative measurements, the significance level was accepted as $\mathrm{p}<, 05$.

The collected data were firstly compared as pre-test/post-test within the groups. The status of the experimental and control group students before the experiment was determined and recorded under three headings. Then the applications were made and the new data of the subjects were recorded under three headings. Comparisons with the control group were needed to fully determine the observed changes. Comparisons were made with the control group in order to determine whether the changes in the experimental group stem from the applications in the experimental process or the natural ongoing process. All the data obtained from the subjects were compared between the groups 
and then in the groups. The Wilcoxon Signed-Rank Test was used for intra-group comparisons of data, and Mann Whitney U Test was used for comparisons between groups.

\section{Findings}

In this section, the values obtained were compared both in groups and between groups and the results were tried to be reached as a result of these comparisons.

\subsection{Experimental Group Pre-test/Post-test Comparisons}

The pre-test and post-test (in-group) comparison of the transcription scores of the students in the experimental group are given in Table 2 .

Table 2. Pre-test/Post-test Comparison of the Experimental Group's Deciphering Skill

\begin{tabular}{|c|c|c|c|}
\hline Subject Number & Pre-test & $\begin{array}{l}\text { Post- } \\
\text { test }\end{array}$ & Difference \\
\hline 1 & 51 & 72,6 & $+11,6$ \\
\hline 2 & 40,3 & 61,3 & +21 \\
\hline 3 & 65,3 & 83 & $+17,7$ \\
\hline 4 & 57 & 74,6 & $+17,6$ \\
\hline 5 & 68,6 & 77,6 & +9 \\
\hline 6 & 37,6 & 54,3 & $+16,7$ \\
\hline 7 & 30,6 & 67,6 & +37 \\
\hline 8 & 49,6 & 54 & $+4,4$ \\
\hline $\bar{X}$ & 50 & 68,12 & $+18,12$ \\
\hline Max. & 68,6 & 83 & $+14,4$ \\
\hline Min. & 30,6 & 54 & $+23,4$ \\
\hline
\end{tabular}

When the pre-test and post-test mean values of the deciphering skills of the experimental group were examined, an increase was observed from 50 to 68,12 . Deciphering skills were found to be an increase of 18.12 in the group. When the highest scores in the group were analysed, it can be said that there is an increase of
23.4 in the lowest points and an increase in general. In the light of these data, it can be said that there is an increase in all grades taken by the experimental group and an increase in the skills of playing piano works

Table 3. Experiment Group Deciphering Scoring Test Results for Pre-Test and Post-Test Using Wilcoxon Signed-Ranks Test Results

\begin{tabular}{|c|c|c|c|c|c|c|}
\hline Measurement & Ranks & $\mathrm{N}$ & Mean A. & Addition R. & $\mathrm{z}$ & $\mathrm{p}$ \\
\hline \multirow{5}{*}{ Experiment G. Decipher Pre-test/Post-test } & Negative R. & 0 & 0,00 & 0,00 & \multirow{5}{*}{$-2,52$} & \multirow{5}{*}{,012 } \\
\hline & Positive R. & 8 & 4,50 & 36 & & \\
\hline & & & & & & \\
\hline & Equal & 0 & & & & \\
\hline & Summation & 8 & & & & \\
\hline
\end{tabular}

The results obtained in the comparison of the scores of the experimental group in the deciphering process according to the data at the pre-test and post-test level were found to be significant according to the $\mathrm{p}<0.05$ level $[\mathrm{z}=-2.52, \mathrm{p}<, 05]$. When the data were analysed, it was observed that there were no students who caused negative decrease in scores, and all students in the group were in positive order. Accordingly, it can be said that the posttest scores of the students in the experimental group increased positively compared to the pre-test scores. 


\subsection{Control Group Pre-test/Post-test \\ Comparisons}

The pre-test and post-test (in-group) comparison of the transcription scores of the students in the control group are given in Table 4.

Table 4. Pre-test/Post-test Comparison of the Control Group's Deciphering Skill

\begin{tabular}{|c|c|c|c|}
\hline Subject Number & Pre- & Post- & Difference \\
\hline 1 & 62 & 71 & +9 \\
\hline 2 & 56 & 57,3 & $+1,3$ \\
\hline 3 & 60 & 60,6 & $+0,6$ \\
\hline 4 & 52,6 & 55,3 & $+2,7$ \\
\hline 5 & 40,6 & 34,6 & -6 \\
\hline 6 & 35,6 & 42,3 & $+6,7$ \\
\hline 7 & 42 & 44 & +2 \\
\hline 8 & 36,6 & 38,6 & +2 \\
\hline $\bar{X}$ & 48,17 & 50,46 & $+2,29$ \\
\hline Max. & 62 & 71 & +9 \\
\hline Min. & 35,6 & 34,6 & -1 \\
\hline
\end{tabular}

Decreasing skills of the control group showed an increase from 48.17 to 50.46 when the pre-test and post-test mean values were analysed. There is an increase of 2.29 in deciphering skills within the group. When the highest scores in the group are analysed, it is seen that there is an increase of 9 points, and the lowest points decrease is -1 . In this sense, it can be said that there is no significant difference between the control group deciphering pretest and post-test data comparisons.

Table 5. Control Group's Deciphering Scoring Test Results for Pre-Test and Post-Test Using Wilcoxon Signed-Ranks Test Results

\begin{tabular}{|c|c|c|c|c|c|c|}
\hline Measurement & Ranks & $\mathrm{N}$ & Mean A. & Addition R. & $\mathrm{z}$ & $\mathrm{p}$ \\
\hline \multirow{4}{*}{$\begin{array}{l}\text { Experiment G. Decipher Pre-test/Post- } \\
\text { test }\end{array}$} & Negative R. & 1 & 6,00 & 6,00 & \multirow{4}{*}{$-1,68$} & \multirow{4}{*}{,092 } \\
\hline & Positive R. & 7 & 4,29 & 30 & & \\
\hline & Equal & 0 & & & & \\
\hline & Summation & 8 & & & & \\
\hline
\end{tabular}

The comparison of the scores of the control group during the deciphering process according to the data at the pre-test and posttest levels was not significant according to the level of $\mathrm{p}<, 05[\mathrm{z}$ $=-2.52, \mathrm{p}<, 05]$. According to these results, it can be said that the scores obtained from pre-test and post-test did not show a positive increase in the deciphering process.

\subsection{Pre-test Comparisons of Experimental and Control Groups}

The comparison of the transcription scores of experimental and control group students at the pre-test level between the groups are given in Table 6. 
Table 6. Pre-test Comparison of the Experiment and Control Group's Deciphering Skill

\begin{tabular}{|c|c|c|c|}
\hline \multirow{3}{*}{$\begin{array}{l}\text { Experiment Group } \\
\text { Rank N. }\end{array}$} & \multicolumn{3}{|c|}{ Control } \\
\hline & Decipher & Group Rank & Decipher \\
\hline & & N. & \\
\hline 1 & 51 & 1 & 62 \\
\hline 2 & 40,3 & 2 & 56 \\
\hline 3 & 65,3 & 3 & 60 \\
\hline 4 & 57 & 4 & 52,6 \\
\hline 5 & 68,6 & 5 & 40,6 \\
\hline 6 & 37,6 & 6 & 35,6 \\
\hline 7 & 30,6 & 7 & 42 \\
\hline 8 & 49,6 & 8 & 36,6 \\
\hline$\overline{\mathrm{X}}$ & 50 & $\overline{\mathrm{X}}$ & 48,7 \\
\hline Max. & 68,6 & Max. & 62 \\
\hline Min. & 30,6 & Min. & 35,6 \\
\hline
\end{tabular}

When the mean scores of deciphering were examined at the pretest level of the subjects, it was seen that the experimental group was 50 and the control group was 48.7. In the highest scores, the experimental group was 68.6 and the control group was 62 . In the lowest scores, the experimental group was 30.6 and the control group was 35.6. When the general averages are taken into consideration, it can be said that there is no significant difference between the deciphering skill scores of both groups.

Table 7. Comparison of Transcription Scores at Pre-test Level between Groups Using Mann Whitney U Test Results for

\begin{tabular}{llllll}
\hline Measurement & Groups & N & $\begin{array}{l}\text { Rank } \\
\text { A. }\end{array}$ & U & p \\
& & & & & \\
\hline $\begin{array}{l}\text { Decipher } \\
\text { Scores }\end{array}$ & Experiment & 8 & 8,75 & & \\
& Control G. & 8 & 8,25 & & \\
& & & & & \\
\hline
\end{tabular}

When the results obtained in the comparison of the scores of the students in the study group, the deciphering process were examined, no significant difference was found according to $\mathrm{p}$ $<0.05$ level. When the average rank values are examined, it can be observed that both groups have close scores. According to this result, the deciphering scores and the deciphering skills of the students in both groups can be considered as equivalent.

\subsection{Post-test Comparisons of Experimental and Control Groups}

The comparison of the transcription scores of the experimental and control group students at the post-test level between the groups is given in Table 8 . 
Table 8. Post-test Comparison of the Experiment-Control Deciphering

\begin{tabular}{|c|c|c|c|}
\hline Experiment Group Rank N & Decipher & Control Group Rank N & Decipher \\
\hline 1 & 72,6 & 1 & 71 \\
\hline 2 & 61,3 & 2 & 57,3 \\
\hline 3 & 83 & 3 & 60,6 \\
\hline 4 & 74,6 & 4 & 55,3 \\
\hline 5 & 77,6 & 5 & 34,6 \\
\hline 6 & 54,3 & 6 & 42,3 \\
\hline 7 & 67,6 & 7 & 44 \\
\hline \multirow[t]{2}{*}{8} & 54 & 8 & 38,6 \\
\hline & 68,12 & $\bar{X}$ & 50,46 \\
\hline Max. & 83 & Max. & 71 \\
\hline Min. & 37,6 & Min. & 34,6 \\
\hline
\end{tabular}

When the test scores of the subjects were examined at the posttest level, it can be seen that the experimental group was 68,12 and the control group was 50,46. While the highest scores were 83 in the experimental group, the control group was 71, the lowest score was 37.6 and the control group was 34.6. When the general averages are examined, it is observed that the experimental group is 17.66 points higher than the control group. In this sense, it can be said that the "Piano Course Work Analysis Form" shows increase in the experimental group compared to the control group.

Table 9. Comparison of Deciphering Scores at Post-test Level between Groups Using Mann Whitney U Test Results

\begin{tabular}{llllll}
\hline Measurement & Groups & N & Rank A. & U & p \\
& & & & & \\
\hline \multirow{2}{*}{ Decipher Scores } & Experiment G. & 8 & 11,25 & \multirow{2}{*}{, 021} \\
& Control G & 8 & 5,75 & & \\
\hline
\end{tabular}

When the results of the post-test deciphering scores of the students in the study group were compared between the groups, a significant difference was found according to the $\mathrm{p}<0.05$ level. When the average order values were examined, it was observed that the significant difference occurred in the direction of the experimental group (11.25 - 5.75). According to this result, it is understood that the scores obtained during the deciphering process indicate the experimental group comes up first at the level of the groups, and that the scores of the students in the experimental group are at a better level than the control group.

\section{Conclusion}

When the post-test results of the music teacher candidates' analysis of the works they are working with in the piano education process are analysed, it is necessary to make comparisons with the pre-test results in order to make full evaluation with the obtained data. We looked at the post-test results of deciphering skills, academic achievements and, in order to make full evaluation of the data obtained from the comparisons made in three sections, and they were evaluated by comparing with the pre-test achievement scores between the groups. The table below shows these comparison results. 
Table 10. Pre-test/Post-test Comparisons of Both Experimental and Control Groups

\begin{tabular}{lllc}
\hline Test Group Average Results & Control Group Average Results \\
\hline \multicolumn{2}{l}{ Success in Piano 73,71} & Success 72,5 & \\
Application & Decipher & Application & Decipher \\
Pre-test & 50 & Pre-test & 48,17 \\
Post-test & 68,12 & Post-test & 50,46 \\
Difference & $+18,12$ & Difference & $+2,29$ \\
\end{tabular}

When the data that the subjects have both within themselves and between the groups is observed, it is seen that there is a significant positive difference in the deciphering skills of the experimental group. The first five-semester piano course averages (piano success) that ensure the equivalence of the groups were 73.71 in the experimental group and 72.5 in the control group. Considering the fact that the piano success scores of the groups were close to each other, it can be said that the groups were also equivalent to each other. As a result of the applications, the experimental group showed an increase of 18.12 points in deciphering skills while the control group showed an increase of 2.29 points.

As a result of the applications of the "Piano Work Analysis Form" that had been applied to the experimental and control groups; it was found that the experimental group made a significant difference in piano lesson sight reading skills.

According to Bağçeci (2003), the student should aim to play well and create questions in his mind in order to achieve this goal. What should be done in order to play well?, How we can overcome problems? or What can be desired to be told in this music work?, such questions created by the student's analytical approach to piano work should be provided. In an effective piano education, it is necessary to understand all aspects of music mentally. In this context, musical analysis is essential in the process of piano education. Considering that the analytic approach helps us to understand the object in front of us, it can be argued that it needs to be analysed in order to understand the content of the work we are going to study in piano education. It can be said that the well-understood work can be transferred more easily on the keyboard, since the well-analysed work is well understood.

In addition to reading the notes while deciphering, there is also a voice over the instrument. During this vocalization, there are mechanical movements according to the structural aspects of the instrument along with the mental dimension of the vocalization
(Öztutgan, 2018). It can be thought that mentally good perception, analysis and comprehension while playing a musical tune will help to transfer this tune on the instrument more quickly and accurately. In this context, it can be said that analysing the work well and learning it mentally will contribute to deciphering skills. It can be concluded that the "Piano Lesson Work Analysis Form" helps to understand the work mentally so that the technical skills can be transferred to the piano more quickly.

The fact that the experimental group showed an increase of 15.58 points compared to the control group in the pre-test-post-test comparisons of the deciphering skills of the experimental-control groups can be considered as an indicator that the 'Piano Lesson Work Analysis Form" had a positive effect on the deciphering skills. Decreasing skills post-test scores increase in the experimental group according to the pre-test scores, and post-test scores do not increase in the control group according to the pretest scores and that can be considered as an indicator of this.

It can be said that the most important reason why the experimental group showed an increase in score in the deciphering skills of the subjects was that the experimental group analysed a wide range of the deciphered work to be played compared to the control group. In order to play the piano works correctly, it is necessary to read the correct notes, correct finger numbers, correct nuances and articulation marks. It can be said that the experimental group noticed a lot of cognitive field information by completing the "Piano Lesson Work Analysis Form" before playing the deciphering works and then deciphering the piece after this stage. It may be thought that the attention of the correct finger numbers, correct nuances, articulation marks and notes before playing the work contributes to the increase in deciphering skill points by acquiring the subjects more familiar with the work. 


\section{Recommendations}

Playing the piano is a performance that requires active use of the mind as well as physical activity and emotional aspects. The more information about the work to be played, the more dominating the cognitive domain is. The more you know about a work, the easier it is to learn and play it.

It is hardly possible to say that focusing on notes is the right approach when deciphering, studying or playing a piece on the piano. By analysing the work in the best way and in all its aspects, it can be said that trying to ensure a permanent learning will be a more correct approach in terms of education. Before playing the piano works, etc. analysis is a very important issue.

Considering that the piano students perform their piano analysis according to their natural abilities, some individuals may be successful and others may be left behind. When the piano instructors recognize the students who have problems in analysing the piano works in terms of playing, it can be considered that they will help them with the analysis mentioned above. In such a case, the use of the "Piano Lesson Work Analysis Form" can be considered as beneficial. However, if desired or required, the instructor may remove items from the work analysis form or add items to the form. In this research, it was tried to provide a scientific approach by taking expert opinions as it was tried to put the students' work analysis on a broad and certain basis in terms of playing the piano. For this purpose, an analysis form that can be used in all works has been tried to be reached. However, the trainer may create analysis items that draw attention to the characteristics of the work to be studied, if there are subjects that the student wants to pay particular attention to, or if it is necessary for the student to analyse on certain topics, not on each subject according to the student's situation. Because the main issue here is to enable the student to analyse.

\section{References}

1. Akyürek, R. (2018). Müzik eğitimcisi yetiştiren kurumlarda orkestra/oda müziği eğitimi etkinlik sürecinin incelenmesi. Journal of Turkish Studies, 13(19), 65-76. Doi:10.7827/TurkishStudies.14034.

2. Bağçeci, S. E. (2003). Piyano eğitiminde müzikal analiz kavramı - kapsamı ve örnek klavye analizleri. Fırat Üniversitesi Sosyal Bilimler Dergisi, 13 (1), 159-176, Elazı̆̆.

3. Baker, N. E. (2008). The effects of peer teaching on undergraduate music majors' achievement and attitude toward sight-reading in the group piano setting.
(Unpublished Doctoral Dissertation). Louisiana State University, Baton Rouge.

4. Bulut, F. (2008). Piyano eğitiminde geleneksel Türk Halk Müziği kaynaklı eserlerin seslendirilmesine yönelik oluşturulan bir "çoklu analiz modeli” ve bu modelin öğrenci başarısı üzerine etkileri. Gazi Üniversitesi Eğitim Bilimleri Enstitüsü Güzel Sanatlar Eğitimi Anabilim Dalı Müzik Öğretmenliği Bilim Dalı, Doktora Tezi.

5. Büyüköztürk, Ş. (2001). Deneysel desenler öntestsontest kontrol grubu desen ve veri analizi. 1. Bask1, Öncü basımevi, Ankara: Pegem A Yayınları.

6. Chaffin, R., \& Imreh, G. (2002). Stages of practice revisited. In R. Chaffin, G. Imreh, \& M. Crawford (Eds.), Practicing perfection: Memory and piano performance (239-246). Mahwah, NJ: Lawrence Erlbaum Associates.

7. Çiftçibaşı, M. C. ve Şaktanlı, S. C. (2017). Hızlı okuma teknikleri eğitiminin piyano deşifre becerisine etkisi. Mehmet Akif Ersoy Üniversitesi Sosyal Bilimler Enstitüsü Dergisi, 9 (18), 35-55.

8. Demirova, G. (2008). Piyano eğitiminde gam tekniği üzerine düşünceler. Mehmet Akif Ersoy Üniversitesi Eğitim Fakültesi Dergisi, 14-23.

9. Ercan, N. (2008). Piyano eğitiminde ilke ve yöntemler. Ankara: Sözkesen.

10. Fenmen, M. (1974). Piyanistin kitabı. Ankara: Akba.

11. Kuo, M. H. (2012). Strategies and methods for improving sight-reading. (Unpublished Doctoral Dissertation). University of Kentucky, Lexington.

12. Kurtuldu, M. K. (2007). Bilgiyi işleme modeline dayalı piyano eğitiminde genel öğrenme stratejilerinin yeri ve görsel imajlar oluşturma yönteminin kullanılabilirlik düzeyi. Gazi Üniversitesi Eğitim Bilimleri Enstitüsü Güzel Sanatlar Eğitimi Anabilim Dalı Müzik Öğretmenliği Bilim Dalı, Doktora Tezi, Ankara.

13. Kurtuldu, M. K. (2014). Piyano öğrencilerinin deşifre becerileri ile piyano dersi başarılarının karşılaştırılması. TSA, 18(3).

14. Küçük A. (1994). Bir piyano eseri nasıl çalışılır. Gazi Üniversitesi Gazi Eğitim Fakültesi Dergisi, Yeni Dönem (Özel Sayı), 185-194.

15. Küpana, M. N. (2012). Piyanoda deşifre öğretimi programının müzik öğretmeni adaylarının piyano dersine yönelik tutumlarına etkisi, 11 (41), 183-194.

16. MacRitchie, J. (2017). Deciphering and Embodying Contemporary Piano Scores: A Commentary on Huisman, Gingras, Dhondt, and Leman. Empirical Musicology Review, 12(1-2), 75-79.

17. Özer, B. (2010). Piyano öğretiminde deşifre becerisinin kazandırılması. Selçuk Üniversitesi Eğitim 
Bilimleri Enstitüsü Güzel Sanatlar Eğitimi Anabilim Dalı Müzik Eğitimi Bilim Dalı, Yüksek Lisans Tezi, Konya.

18. Öztutgan, K. (2018). Mesleki müzik eğitimi veren kurumlarda klasik gitar deşifresini geliştirmeye yönelik bir metot önerisi. Ondokuz Mayıs Üniversitesi Eğitim Bilimleri Enstitüsü, Güzel Sanatlar Eğitimi Anabilim Dalı, Doktora Tezi, Samsun.

19. Öztutgan, K. ve Akbulut, F. (2019). Müzikal deşifrenin boyutları ve etken faktörleri. SDÜ Güzel Sanatlar Fakültesi Sanat Dergisi, 12 (23), 65-87.

20. Selen, B. ve Aşkın, C. (2009). Piyano eğitiminde çözümleme destekli çalışma metodu ve uygulanışı. İTÜ Dergisi/B, 6 (1), 53-63.

21. Tufan, S. (2000). Piyano eğitiminde deşifre çalışmaları. G.Ü. Gazi Eğitim Fakültesi Dergisi, 20 (3), 101-104.

22. Yılmaz, N. (2006). Uludağ üniversitesi eğitim fakültesi gse bölümü müzik eğitimi anabilim dalında uygulanan piyano eğitiminin değerlendirilmesi. Ulusal Müzik Eğitimi Sempozyumu Bildiri Kitabı, (554-593), 2628 Nisan, Pamukkale Üniversitesi Eğitim Fakültesi, Denizli. 